\title{
Gambaran Efek Samping dan Kepatuhan Terapi Antiretroviral pada Pasien HIV di Rumah Sakit Dr. Hasan Sadikin Bandung Tahun 2015
}

\author{
Dewi Puspasari ${ }^{1}$, Rudi Wisaksana ${ }^{2}$, Rovina Ruslami ${ }^{3}$ \\ ${ }^{1}$ Fakultas Kedokteran, Universitas Padjadjaran \\ ${ }^{2}$ Departemen Ilmu Penyakit Dalam, Fakultas Kedokteran, Universitas Padjadjaran / \\ Rumah Sakit Umum Hasan Sadikin, Bandung, Indonesia \\ ${ }^{3}$ Departemen Farmakologi dan Terapi, Fakultas Kedokteran, Universitas Padjadjaran
}

\begin{abstract}
Abstrak
Jawa Barat berada dalam posisi 4 besar jumlah kasus baru infeksi HIV terbanyak di Indonesia selama 20122014. Pengidap HIV memerlukan terapi Antiretroviral (ARV) agar perkembangan penyakit, komplikasi dan penularannya dapat dicegah. Penelitian ini bertujuan untuk mengetahui gambaran efek samping dan kepatuhan terapi antiretroviral pada pasien HIV berbagai stadium. Penelitian ini merupakan penelitian deskriptif kuantitatif yang dilaksanakan pada September-November 2016. Data sekunder diambil secara restropektif dari 201 rekam medik (total sampling) pasien HIV baru di Klinik Teratai RSUP Dr. Hasan Sadikin periode Januari-Desember 2015. Hasil menunjukkan persentase stadium pasien HIV yaitu stadium 4 (41,8\%), 1(25,4\%), 3(24,9\%) dan 2(7,9\%). Kebanyakan pasien terdiagnosis dan/atau berobat ketika sakitnya sudah parah atau justru saat screening pada kelompok berisiko. Jumlah pasien yang mengalami efek samping ARV lebih banyak (50,7\%) dibanding yang tidak. Efek samping yang paling banyak muncul diantaranya mual, pusing, gatal dan ruam kemerahan pada kulit. Efek samping yang timbul bergantung pada variabilitas kadar ARV dalam plasma. Persentase pasien yang patuh menjalani terapi ARV adalah 58,2\%. Tingkat kepatuhan sangat dipengaruhi oleh pengetahuan dan keyakinan akan pentingnya pengobatan. Disimpulkan bahwa efek samping yang timbul bervariasi dan dialami oleh lebih banyak pasien, jumlah pasien patuh menjalani terapi antiretroviral lebih dari setengah total jumlah pasien.
\end{abstract}

Kata kunci : Antiretroviral, Efek samping, Kepatuhan, Pasien HIV, Stadium klinis.

\section{Overview of Antiretroviral Therapy Adherence and Side Effects in HIV Patients at Dr. Hasan Sadikin Hospital in 2015}

\begin{abstract}
West Java is in the 4th position of the largest HIV infection cases in Indonesia during 2012-2014. People who live with HIV infection need antiretroviral treatment (ARV) in order to prevent the disease development, complications and transmission. This study aimed to describe the side effects and adherence of antiretroviral therapy in various $H I V$ stage that can be used as consideration in management of patients. This research is quantitative descriptive design that use retrospective secondary data taken from the medical records of HIV patients in the Klinik Teratai Dr. Hasan Sadikin Hospital in January to December, 2015. This study uses all existing samples of patients and taken during September-November 2016. After the process of inclusion and exclusion, finally obtained 201 patients as sample. The result shows the clinical stage of HIV patients are stage 4 (41.8\%), 1 (25.4\%), 3 (24.9\%) and 2 (7.9\%). The patients mostly diagnosed when the disease is severe, others are diagnosed by screening in population at risk. The amount of patients that having side effects $(50,7 \%)$ are greater than not. The side effects that mostly occur such as nausea, dizziness, itching and rash depend on variability of ARV level in plasma. The percentage of patients that adhere (58.2\%) to antiretroviral therapy is higher than non-adhere. The adherence level is very influenced by the patient's knowledge and believe about medication. It's concluded that the manifestation of side effect is vary and experienced by many patients. The amount of adhere patients are more than half of the total patients.
\end{abstract}

Keywords : Adherence, Antiretroviral, Clinical stage, HIV patients, Side effects.

Korespondensi:

Dewi Puspasari

Fakultas Kedokteran Universitas Padjadjaran

Jl. Raya Bandung-Sumedang KM 21 Jatinangor, Sumedang

Mobile : 082117687885

Email : puspasaridewi10@gmail.com 


\section{Pendahuluan}

HIV atau Human Immunodeficiency Virus adalah sejenis virus yang menginfeksi sel limfosit-CD4 dan menyebabkan turunnya kekebalan tubuh manusia. Perkembangan dari stadium infeksi HIV ialah menjadi Acquired Immunodeficiency Syndrome atau AIDS, yaitu sekumpulan gejala penyakit yang timbul akibat turunnya kekebalan tubuh. ${ }^{1,2}$ Infeksi HIV memiliki 4 stadium klinis dimana stadium 1 dapat tidak nampak gejala infeksi, stadium 2, 3 dan 4 semakin parah seiring meningkatnya stadium. ${ }^{3}$

Setelah 3 tahun berturut-turut (2010-2012) cukup stabil, perkembangan jumlah kasus baru HIV positif di Indonesia pada tahun 2013 dan 2014 kembali mengalami peningkatan secara signifikan. Tahun 2012 terdapat 21.511 kasus HIV postif baru, naik menjadi 29.037 pada 2013 dan naik lagi menjadi 32.711 pada 2014. Jawa Barat berada dalam posisi 4 besar jumlah kasus baru infeksi HIV terbanyak di Indonesia bersama dengan Jakarta, Papua dan Jawa Timur selama 2012-2014. ${ }^{2}$ Fakta ini banyak luput dari perhatian berbagai kalangan, maka dari itu dibutuhkan pembaharuan informasi mengenai jumlah orang dengan HIV-AIDS (ODHA) setiap tahunnya guna menyusun strategi pencegahan penularan dan memberi penanganan yang tepat bagi ODHA.

Pengidap HIV memerlukan pengobatan Antiretrovirus (ARV) untuk menurunkan jumlah virus di dalam tubuh agar tidak masuk ke dalam stadium AIDS, dan pengidap AIDS memerlukan pengobatan ARV untuk mencegah terjadinya infeksi oportunistik dengan berbagai komplikasinya. ${ }^{4}$ Penelitian menunjukkan bahwa untuk mencapai tingkat supresi virus HIV yang optimal, setidaknya 95\% dari semua dosis tidak boleh terlupakan. Artinya pasien dikatakan patuh minum ARV jika minimal $95 \%$ obat diminum. ${ }^{5}$

Seperti halnya obat lainnya, obat-obatan untuk terapi HIV juga memiliki efek samping dan obat ini harus diminum seumur hidup. ${ }^{1,4}$ Maka dari itu kenyamanan dan peminimalisiran efek samping sangat diharapkan oleh setiap pasien HIV. Langkah awal yang perlu dilakukan ialah mengetahui apa saja efek samping yang timbul. Kemudian dapat dilakukan antisipasi dan edukasi pada pasien.

Adanya efek samping ini dapat mempengaruhi kepatuhan minum obat yang harus dijalani seumur hidup oleh pasien. Oleh karena itu, penelitian ini bertujuan untuk mengetahui gambaran efek samping dan kepatuhan terapi ARV pada pasien HIV berbagai stadium di Rumah Sakit Umum Pusat (RSUP) Dr. Hasan Sadikin Bandung. Penelitian ini diharapkan dapat menjadi pertimbangan tambahan dan memengaruhi kebijakan terapi antiretroviral. Angka kejadian efek samping dan kepatuhan terapi ini sekaligus dapat menjadi tolak ukur keberhasilan program penanganan dan pengendalian HIV yang telah dijalankan

\section{Metode}

Penelitian dilakukan menggunakan studi desain deskriptif kuantitatif. Objek penelitian merupakan data sekunder yang diambil secara restropektif dari seluruh (total sampling) rekam medik pasien HIV di Klinik Teratai RSUP Dr. Hasan Sadikin Bandung. Seluruh penelitian dilakukan setelah mendapat Surat Etik yang dikeluarkan oleh Komite Etik Fakultas Kedokteran Universitas Padjadjaran dengan nomor 665/UN6.C1.3.2/ KEPK/PN/2016. Peneliti tidak memandang ras, suku, agama dan latar belakang pasien sehingga semua diperlakukan adil. Proses pengambilan data berlangsung pada bulan SeptemberNovember 2016.

Data yang diambil memiliki kriteria inklusi berupa rekam medik pasien dewasa yang terdaftar menjadi pasien baru sejak 1 Januari 31 Desember 2015. Kemudian dieksklusi jika data tidak lengkap (tidak terdapat data identitas, usia, jenis kelamin dan stadium klinis) atau tidak terbaca. Variabel pada penelitian ini adalah stadium klinis, efek samping dan kepatuhan antiretroviral therapy (ART).

Sampel penelitian dikelompokkan berdasarkan usia, dengan definisi usia kronologis yaitu jumlah tahun seseorang sudah hidup, diukur dari tahun kelahiran individu hingga waktu pertama berobat dan bukan merupakan pembulatan usia ke ulang tahun yang belum terlewati. ${ }^{6}$ Sampel juga dikelompokkan berdasarkan diagnosis stadium yang diderita saat pasien pertama berobat. Tingkatan stadium menurut World Health Organization (WHO) untuk HIV/AIDS menekankan penggunaan parameter klinis sebagai panduan keputusan untuk manajemen pasien. ${ }^{3}$

Definisi operasional yang digunakan dalam penelitian ini diantaranya efek samping merupakan gejala lain yang tidak diharapkan muncul disamping efek manfaat obat. ${ }^{7}$ Selanjutnya berdasarkan WHO kepatuhan dapat diketahui dengan menggunakan pengukuran tidak langsung (indirect measure), salah satunya menggunakan Visual Analogue Scale (VAS). Pasien dikatakan patuh jika persentase kepatuhan lebih dari sama dengan $95 \%{ }^{8,9}$ Analisis dilakukan secara deskriptif dengan menghitung jumlah dan persentase. 


\section{Hasil}

Jumlah sampel yang didapatkan pada penelitian ini yaitu 201 pasien. Proporsi pasien HIV terbanyak adalah stadium 4, diikuti oleh stadium 1, 3 dan 2. Modus dan mean usia pasien berturut-turut adalah 26 dan 31 tahun. Hampir seluruh pasien masih berada dalam usia produktif $(99,5 \%)$ ketika pertama kali masuk menjadi pasien di Klinik Teratai. Pasien HIV didominasi oleh laki-laki dengan perbandingan 2,2: 1 untuk laki-laki dan perempuan. Dari 62 pasien perempuan, terdapat 5 orang yang pernah hamil selama menjalani pengobatan. Sebanyak 50,7\% pasien mengalami efek samping setelah diberikan terapi ARV.

Dari 102 pasien yang merasakan adanya efek samping, didapatkan 199 kejadian efek samping. Sebanyak 35 pasien $(34,3 \%)$ mengeluhkan mual setelah meminum ARV. Efek samping terbanyak yang dirasakan pasien adalah mual, pusing, gatal dan ruam. Sebanyak 144 pasien $(71,6 \%)$ diberikan obat fixed dose combination (FDC) yang berisi tenofovir, lamivudine dan efavirenz. Sisanya diberi kombinasi obat lain seperti zidovudine, lamivudine dan nevirapine; stavudine, lamivudine dan nevirapine; abacavir, lamivudine dan efavirenz. Dalam penelitian ini digunakan Algoritma Naranjo untuk membantu menentukan kejadian efek samping. Efek buruk yang dirasakan pasien termasuk dalam kategori "possible" dan "probable". Daftar efek samping yang dikeluhkan pasien pada tabel diketahui telah masuk menjadi laporan efek samping obat ARV. Efek samping pada tabel adalah jenis keluhan yang dirasakan pasien tanpa melihat berapa kali efek samping tersebut muncul.

Dari 201 pasien HIV, yang melakukan kunjungan follow up sebanyak 91 pasien sehingga penilaian kepatuhan hanya dilakukan pada pasien tersebut. Pasien yang patuh menjalani terapi ARV sebanyak 58,2\%. Persentase terbesar kategori pasien adalah pasien HIV stadium 4 yang patuh meminum ARV walaupun terdapat efek samping yang muncul.

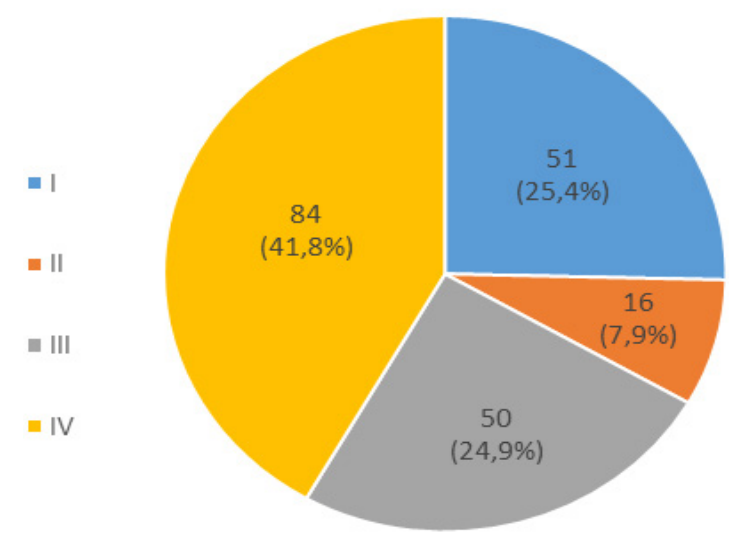

Gambar 1 Proporsi Stadium Klinis Pasien Baru HIV di Klinik Teratai RSUP Dr. Hasan Sadikin periode 1 Januari - 31 Desember 2015

Tabel 1 Karakteristik Pasien HIV berdasarkan Stadium Klinis

\begin{tabular}{|c|c|c|c|c|c|}
\hline \multirow{2}{*}{ Karakteristik } & \multicolumn{4}{|c|}{ Stadium Klinis } & \multirow{2}{*}{ Total (\%) } \\
\hline & 1 & 2 & 3 & 4 & \\
\hline \multicolumn{6}{|l|}{ Usia (tahun) } \\
\hline Produktif (18-64) & 51 & 16 & 50 & 83 & $200(99,5 \%)$ \\
\hline Tua $(\geq 65)$ & 0 & 0 & 0 & 1 & $1(0,5 \%)$ \\
\hline \multicolumn{6}{|l|}{ Jenis Kelamin } \\
\hline Laki-laki & 30 & 10 & 37 & 62 & $139(69,2 \%)$ \\
\hline Perempuan & 21 & 6 & 13 & 22 & $62(30,8 \%)$ \\
\hline \multicolumn{6}{|l|}{ Efek Samping } \\
\hline Ada & 22 & 10 & 21 & 49 & $102(50,7 \%)$ \\
\hline Tidak Ada & 28 & 5 & 27 & 31 & $91(44,8 \%)$ \\
\hline Non-ARV & 1 & 1 & 2 & 4 & $8(3,9 \%)$ \\
\hline Total & 51 & 16 & 50 & 84 & $201(100 \%)$ \\
\hline
\end{tabular}


Dewi Puspasari : Gambaran Efek Samping dan Kepatuhan Terapi Antiretroviral pada Pasien HIV di Rumah Sakit Dr. Hasan Sadikin Bandung Tahun 2015

Tabel 2 Efek Samping Terapi ARV Pasien HIV di Klinik Teratai RSUP Dr. Hasan Sadikin

\begin{tabular}{|c|c|c|c|c|c|c|}
\hline \multirow{2}{*}{ Efek Samping } & \multicolumn{4}{|c|}{ Stadium } & \multirow{2}{*}{ Total } & \multirow{2}{*}{$\begin{array}{l}\text { Persentase Pasien } \\
(n=102)\end{array}$} \\
\hline & 1 & 2 & 3 & 4 & & \\
\hline Mual & 7 & 4 & 5 & 19 & 35 & $34,3 \%$ \\
\hline Pusing & 9 & 7 & 7 & 10 & 33 & $32,4 \%$ \\
\hline Gatal & 5 & 3 & 5 & 17 & 30 & $29,4 \%$ \\
\hline Ruam & 5 & 2 & 3 & 7 & 17 & $16,7 \%$ \\
\hline Muntah & 3 & 2 & 1 & 8 & 14 & $13,7 \%$ \\
\hline Diare & 1 & 1 & 2 & 10 & 14 & $13,7 \%$ \\
\hline Nyeri kepala & 2 & 2 & 1 & 9 & 14 & $13,7 \%$ \\
\hline Lemah badan & 2 & 1 & 3 & 5 & 11 & $10,8 \%$ \\
\hline Alergi & 2 & 2 & 2 & 4 & 10 & $9,8 \%$ \\
\hline Gangguan tidur, mimpi buruk & 1 & 1 & 0 & 2 & 4 & $3,9 \%$ \\
\hline Anemia & 0 & 1 & 1 & 1 & 3 & $2,9 \%$ \\
\hline Gynecomastia & 0 & 0 & 1 & 2 & 3 & $2,9 \%$ \\
\hline Hepatitis & 0 & 0 & 1 & 1 & 2 & $1,9 \%$ \\
\hline Osteomalasia & 0 & 0 & 2 & 0 & 2 & $1,9 \%$ \\
\hline Cemas (anxietas) & 0 & 0 & 1 & 1 & 2 & $1,9 \%$ \\
\hline Depresi & 0 & 0 & 1 & 0 & 1 & $0,9 \%$ \\
\hline Kencing sedikit & 0 & 1 & 0 & 0 & 1 & $0,9 \%$ \\
\hline Mulut kering & 0 & 0 & 1 & 0 & 1 & $0,9 \%$ \\
\hline Kulit kering & 0 & 0 & 0 & 1 & 1 & $0,9 \%$ \\
\hline Nyeri perut & 0 & 0 & 0 & 1 & 1 & $0,9 \%$ \\
\hline Total & 37 & 27 & 37 & 98 & 199 & $100 \%$ \\
\hline
\end{tabular}

Tabel 3 Kepatuhan Terapi ARV Berdasarkan Stadium Pasien HIV di Klinik Teratai RSUP Dr. Hasan Sadikin

\begin{tabular}{ccc}
\hline Stadium & Patuh & Tidak Patuh \\
\hline 1 & $13(14,3 \%)$ & $9(9,9 \%)$ \\
2 & $6(6,6 \%)$ & $3(3,3 \%)$ \\
3 & $15(16,5 \%)$ & $9(9,9 \%)$ \\
4 & $19(20,9 \%)$ & $17(18,7 \%)$ \\
Total & $53(58,2 \%)$ & $38(41,8 \%)$ \\
\hline
\end{tabular}

Tabel 4 Kejadian Efek Samping dan Kepatuhan Terapi Pasien HIV Berdasarkan Stadium di Klinik Teratai RSUP Dr. Hasan Sadikin

\begin{tabular}{cccccc}
\hline \multirow{2}{*}{ Stadium } & \multicolumn{2}{c}{ Ada Efek Samping } & \multicolumn{2}{c}{ Tidak Ada Efek Samping } & \multirow{2}{*}{ Total } \\
\cline { 2 - 5 } & Patuh (\%) & Tidak Patuh (\%) & Patuh (\%) & Tidak Patuh (\%) & \\
\hline 1 & $7(7,69 \%)$ & $6(6,59 \%)$ & $6(6,59 \%)$ & $3(3,29 \%)$ & 22 \\
2 & $5(5,49 \%)$ & $3(3,29 \%)$ & $1(1,09 \%)$ & $0(0 \%)$ & 9 \\
3 & $7(7,69 \%)$ & $5(5,49 \%)$ & $8(8,79 \%)$ & $4(4,39 \%)$ & 24 \\
4 & $13(14,28 \%)$ & $11(12,08 \%)$ & $6(6,59 \%)$ & $6(6,59 \%)$ & 36 \\
Total & $32(35,2 \%)$ & $25(27,5 \%)$ & $21(23,1 \%)$ & $13(14,3 \%)$ & 91 \\
\hline
\end{tabular}




\section{Pembahasan}

Dalam penelitian ini didapatkan bahwa hampir seluruh pasien $(99,5 \%)$ berada dalam usia produktif dengan rentang 18-64 tahun. Hasil ini sesuai dengan penelitian yang dilakukan oleh Teklay dkk. ${ }^{10}$ yang juga menemukan bahwa kelompok usia terbanyak penderita HIV pada usia 15-50 tahun yaitu 93,3\% dari jumlah sampel, sisanya berusia $<15$ tahun dan $>50$ tahun. Hasil penelitian Freeman dan Anglewicz. ${ }^{11}$ menyatakan bahwa prevalensi untuk usia 65 tahun dan lebih secara signifikan rendah. Dilaporkan hal ini terjadi karena aktivitas seksual yang berkurang akibat bertambahnya usia dan partner seksual yang lebih sedikit. ${ }^{11}$ Angka yang tinggi pada usia produktif ini tentunya sangat merugikan berbagai pihak, bukan hanya pasien yang menderita HIV tapi juga lingkup yang lebih luas seperti negara yang kehilangan kemampuan produktivitas maksimal masyarakatnya.

Berdasarkan karakteristik demografik lainnya, sampel laki-laki $(69,2 \%)$ lebih banyak dibanding perempuan $(30,8 \%)$. Hansana dkk. $^{5}$ juga mendapat hasil penelitian dengan jumlah lakilaki lebih banyak yaitu 52,6\%. Laki-laki lebih sering berganti dan memiliki banyak pasangan seksual. ${ }^{11}$ Peneliti menemukan bahwa sebagian pasien merupakan lesbian, gay, biseksual dan transgender (LGBT) dan mayoritas adalah lakilaki.

Dalam penelitian ini diketahui bahwa stadium HIV paling banyak adalah stadium 4, 1, 3 dan 2 dengan jumlah pasien stadium 1 dan 3 yang hampir sama. Sedangkan hasil penelitian Widiyanti dan Sandy ${ }^{12}$ yang bertempat di Jayapura menemukan stadium paling banyak adalah stadium 3,2 , 1 dan 4. Banyak faktor yang mempengaruhi jumlah dan stadium penyakit pasien, diantaranya yaitu keterlambatan diagnosis, adanya stigma sosial dan diskriminasi yang membuat pasien menyembunyikan penyakitnya dan tidak melakukan pengobatan. ${ }^{13}$ Hal ini membuat jumlah HIV/AIDS stadium 4 tinggi karena pasien mengunjungi pusat pelayanan kesehatan ketika sudah dalam kondisi buruk. Selain itu semakin gencarnya program pemerintah mengenai Voluntary Counselling Test (VCT) membuat banyak kelompok beresiko melakukan screening sehingga dapat ditemukan kasus HIV dengan stadium yang masih awal, dalam penelitian ini ditemukan bahwa jumlah pasien stadium 1 cukup tinggi.

Pengobatan infeksi HIV yang efektif membutuhkan minimal 3 rejimen obat. Sebanyak 50,7\% pasien paling sedikit mengalami 1 kali efek samping dari obat-obat ARV. Senada dengan hasil tersebut, penelitian yang dilakukan Teklay dkk. ${ }^{10}$ juga menemukan bahwa $65,5 \%$ pasien pernah mengalami efek samping. Efek samping berupa rash, hepatotoksisitas, keluhan gastrointestinal dan sistem saraf pusat (SSP) terjadi di awal pengobatan pada interval paling sering 2 minggu. ${ }^{10}$ Pada penelitian ini diketahui bahwa efek samping yang paling banyak dialami adalah mual, pusing, gatal dan ruam. Efek samping yang paling sering terjadi adalah terkait sistem saraf pusat yang tidak spesifik sehingga menyebabkan mual, pusing, vertigo dan sakit kepala. Mual merujuk pada perasaan subjektif ingin muntah, hal ini timbul karena teraktivasinya pusat muntah yang berada di medulla oblongata. ${ }^{14}$ Studi pada data farmakogenomik dilaporkan adanya variabilitas genotipe pada sebagian orang sehingga ARV dalam plasma meningkat dan menimbulkan efek samping seperti reaksi hipersensitivitas yang dapat ditandai dengan adanya gatal dan ruam. Banyak studi menyebutkan bahwa toksisitas adalah alasan utama untuk mengganti jenis ARV ${ }^{10}$ Beberapa pasien dalam penelitian ini juga mengalami penggantian obat dikarenakan efek samping, alergi ataupun toksisitas. Obat-obat yang termasuk dalam 1 golongan memiliki efek samping yang mirip dan bahkan sama.

Dalam penelitian ini didapatkan hasil bahwa pasien patuh lebih banyak yaitu 58,2\%. Penelitian yang dilakukan oleh Wisaksana dkk. ${ }^{15}$ menemukan bahwa jumlah pasien yang patuh menjalani terapi ARV berada diatas angka $80 \%$ untuk masing-masing perhitungan indikator kepatuhan. Mayoritas pasien $(91,0 \%)$ merasa lebih baik sejak memulai terapi ARV. ${ }^{5}$

Sebanyak 38 pasien $(41,8 \%)$ tidak patuh menjalani terapi ARV. Dalam penelitian yang dilakukan Hansana dkk. ${ }^{5}$ juga dilaporkan adanya $39,1 \%$ pasien yang tidak patuh terhadap pengobatan dan dosis yang telah diresepkan. Alasan utama adanya ketidakpatuhan ini dikarenakan pasien terlalu sibuk dan lupa meminum obat. Selain itu sebanyak 12,4\% pasien dilaporkan pernah melewatkan jadwal kunjungan rutin ke dokter. Alasannya masih sama yaitu terlalu sibuk, namun pasien lain beralasan tidak memiliki uang untuk membiayai perjalanan ke pusat kesehatan atau karena pusat kesehatan tersebut terlalu jauh dari tempat tinggal. ${ }^{5}$ Stigma sosial yang diterima pasien juga sangat mempengaruhi kepatuhan. Banyak orang melabeli mereka dengan stigma seksual negatif sehingga pasien merasa terhina dan malu. Hal ini membuat pasien tidak semangat untuk menjalani pengobatan, menyerah dan tidak patuh. ${ }^{13}$

Efek sampingARV merupakan salah satualasan utama yang menyebabkan pasien HIV menunda atau menghentikan pengobatan sehingga tingkat kepatuhan rendah. Efek samping ini tidak hanya 
menimbulkan sakit fisik dan ketidaknyamanan tetapi juga memengaruhi banyak aspek kehidupan sehari-hari seperti pekerjaan yang terkendala. Pasien yang mengalami efek samping lebih memilih pengobatan alternatif dan pelengkap. Manajemen terhadap gejala efek samping secara efektif meningkatkan kepatuhan, baik itu dengan perubahan perilaku dan diet ataupun dengan upaya farmakologi. ${ }^{16}$

Dalam penelitian ini diketahui bahwa kategori pasien paling banyak adalah pasien stadium 4 dan patuh menjalani terapi ARV walaupun terdapat efek samping yang muncul. Penelitian yang dilakukan oleh Mbirimtengerenji dkk. ${ }^{17}$ mendapatkan hasil bahwa kepatuhan besar dipengaruhi oleh tingkat pengetahuan dan keyakinan akan pentingnya pengobatan. Sebaliknya faktor yang mempengaruhi ketidakpatuhan adalah tingkat pengetahuan yang rendah. ${ }^{17}$ Pasien yang memiliki pengetahuan baik mengenai pentingnya pengobatan terlepas dari efek samping yang dirasakan memiliki kepatuhan yang cukup baik. Penelitian sebelumnya oleh Wisaksana dkk. ${ }^{15}$ di RSHS tahun 1996 hingga 2008 menunjukkan bahwa mayoritas pasien (40,25\%) merupakan lulusan Sekolah Menengah Atas (SMA dan kesetaraannya) sehingga cukup baik dalam menerima dan merespon edukasi yang diberikan. Dalam penelitian ini, pasien stadium 4 dengan berbagai komplikasinya memiliki fungsi organ yang sudah menurun sehingga efek samping lebih mudah timbul, tetapi dengan pengetahuan dan kesadaran mengenai pentingnya pengobatan mereka memiliki tingkat kepatuhan yang tinggi.

Keterbatasan dalam penelitian ini diantaranya belum adanya standar pasti untuk menentukan efek samping dan penggunaan VAS dalam menilai kepatuhan minum obat masih memperlihatkan subjektivitas yang tinggi.

Simpulan, Persentase terbanyak kategori pasien adalah HIV stadium 4, pasien merasakan efek samping dan pasien patuh menjalani terapi ARV. Banyak faktor yang mempengaruhi munculnya efek samping dan tingkat kepatuhan, dengan edukasi dan kerjasama yang baik antara pasien dan dokter maka efek samping dapat diminimalisir dan tingkat kepatuhan dapat ditingkatkan. Pada kejadian efek samping yang tidak kunjung membaik akan dilakukan penggantian jenis ARV pada pasien.

Untuk penelitian lebih lanjut disarankan agar pencatatan rekam medis dapat dilakukan dengan lebih lengkap dan jelas. Selain itu, diharapkan terdapat penelitian yang mengukur kepatuhan pasien berdasarkan persentase rejimen obat yang tersisa dibagi obat yang diresepkan kemudian dapat dibandingkan dengan hasil kepatuhan dari VAS dalam penelitian ini.
Implikasi yang dapat diterapkan oleh klinisi terkait efek samping dan kepatuhan salah satunya adalah konseling terhadap pasien mengenai pentingnya pengobatan ARV untuk meningkatkan kualitas hidup dan tidak boleh menghentikan pengobatan, jika efek samping tersebut terusmenerus dirasakan, obat dapat diganti.

\section{Daftar Pustaka}

1. Direktorat Jendral Pengendalian Penyakit dan Penyehatan Lingkungan. Informasi Pengendalian Penyakit dan Penyehatan Lingkungan. Kementrian Kesehatan RI; 2013:31-35.

2. Kementrian Kesehatan Republik Indonesia. Profil Kesehatan Indonesia 2014. Kementrian Kesehatan RI; 2015:138-142.

3. Mutevedzi PC, Newell M. A missing piece in the puzzle: HIV in mature adults in subSaharan Africa. Futur Virol. 2012;6(6):75567.

4. Johnson MO, Neilands TB. Coping with HIV treatment side effects. AIDS Behav. 2008;11(4):575-85.

5. Hansana, V., Snchaisuriya, P., Durham, J., Sychareun, V., Chaleunvong, K., Boonyaleepun, S., Schelp, F.P. Adherence to Antiretroviral Therapy (ART) among People Living With HIV (PLHIV): a cross-sectional survey to measure in Lao PDR. BMC Public Health. 2013;13(1):1-11.

6. Sanderson, W., \& Scherbov, S. Rethinking Age and Aging. Population Bulletin. 2008;63(4), 3-16.

7. Katz, N.P. The measurement of symptoms and side effects in clinical trials of chronic pain. Contemporary Clinical Trials. 2012;33(5), 903-911.

8. World Health Organization. Development of a Multi-Method Tool to Measure ART Adherence in Resource-Constrained Settings : The South Africa Experience. 2007:6-9.

9. Kalichman SC, Amaral CM, Swetzes C, Jones M, Macy R, Kalichman MO CC. A Simple Single Item Rating Scale to Measure Medication Adherence: Further Evidence for Convergent Validity. J Int Assoc Physicians AIDS Care. 2011;8(6):367-74.

10. Teklay G, Legesse B, Legesse M. Adverse Effects and Regimen Switch among Patients on Antiretroviral Treatment in a Resource Limited Setting in Ethiopia. Pharmacovigilance. 2013;1(4):1-5.

11. Freeman E, Anglewicz P. HIV Prevalence and Sexual Behaviour at Older Ages in Rural Malawi. Int J STD AIDS. 2013;23(7):490-6. 
12. Widiyanti M, Sandy S. Gambaran Subtipe HIV-1 dengan kadar CD4, Stadium Klinis, dan Infeksi Oportunistik Penderita HIV / AIDS di Kota dan Kabupaten Jayapura, Papua. MKB. 2016;48(10):1-6.

13. Saki M, Mohammad S, Kermanshahi K, Mohammadi E. Perception of Patients With HIV / AIDS From Stigma and Discrimination. Iran Red Crescent Med J. 2015;17(6):1-7.

14. Chimirri S, Aiello R, Mazzitello C, Mumoli L, Palleria C, Altomonte M, et al. Vertigo/ dizziness as a Drugs' adverse reaction. J Pharmacol Pharmacother. 2013;4(1):104-9.

15. Wisaksana $\mathrm{R}$, Indrati $\mathrm{AR}$, Fibriani $\mathrm{A}$, Rogayah E, Sudjana P, Djajakusumah TS, et al. Response to First Line Antiretroviral
Treatment Among HIV-infected Patients With and Without A History of Injecting Drug Use in Indonesia. Addiction. 2010;105(6);105561.

16. Chen W, Shiu C, Yang JP, Simoni JM, Fredriksen- I, Lee TS, et al. Antiretroviral Therapy (ART) Side Effect Impacted on Quality of Life, and Depressive Symptomatology: A Mixed-Method Study. J AIDS Clin Res. 2013; 4(218):1-16.

17. Mbirimtengerenji ND, Jere G, Lengu S, Maluwa A. Factors That Influence AntiRetroviral Therapy Adherence among Women in Lilongwe Urban Health. World J AIDS. 2013;3(1):16-25. 